\title{
GEDUNG GALERI KESENIAN DI MENTENG, JAKARTA PUSAT
}

\author{
Stefanus Kevin ${ }^{1)}$, Stephanus Huwae ${ }^{2)}$ \\ 1) Program Studi S1 Arsitektur, Fakultas Teknik, Universitas Tarumanagara, stevkevinz@gmail.com \\ 2) Program Studi S1 Arsitektur, Fakultas Teknik, Universitas Tarumanagara, ituthuwae@gmail.com
}

\begin{abstract}
Abstrak
Bidang pariwisata merupakan sebuah bidang yang sangat berpotensi meningkatkan penghasilan devisa suau negara ataupun daerah. Architourism of The Metropolis merupakan tema Tugas Akhir semester 8 di Universitas Tarumanagara. Dengan adanya tema ini, arsitek diminta merancang sebuah kawasan pariwisata di tengah kota Jakarta dengan sub tema hiburan dan pertunjukan. Hiburan pertunjukan sendiri memiliki sebuah wisata pertunjukan di mana sebuah kawasan tersebut memberikan tontonan bagi wisatawan yang datang dan memberikan penagalman berbeda dari keseharian pengunjung.
\end{abstract}

Kata kunci: architourism of the metropolis, galeri, kesenian, lukis, patung, pertunjukan

\begin{abstract}
The field of tourism is a field that has the potential to increase foreign exchange earnings of a country or region. Architourism of The Metropolis is the theme of the 8th semester Final Project at Tarumanagara University. With this theme, architects were asked to design a tourism area in the center of Jakarta with sub-themes of entertainment and performances. Entertainment shows themselves have a performance tour where a region provides a spectacle for tourists who come and provide different handling from the daily lives of visitors.
\end{abstract}

Keywords: architourism of the metropolis, art gallery, painting, performances, sculpture

\section{PENDAHULUAN}

\section{Latar Belakang}

Metropolis merupakan pengertian dari kota besar yang merupakan pusat ekonomi, politik, dan budaya yang signifikan untuk suatu negara atau wilayah, dan pusat penting untuk koneksi, perdagangan, dan komunikasi regional atau internasional. Istilahnya adalah Yunani Kuno ( yang mengirimkan pemukim. Ini kemudian digeneralisasikan ke kota yang dianggap sebagai pusat kegiatan tertentu, atau kota besar yang penting di suatu negara.

Sebagai ibu kota negara, Kota Jakarta pantas menjadi satu kota yang banyak dituju dan dikunjungi berbagai elemen masyarakat dari berbagai penjuru daerah. Berpredikat sebagai ibu kota negara, pembangunan di Kota Jakarta memang terasa lebih pesat karena di sinilah pusat perekonomian bangsa sebagian besar dikontrol dan digerakkan. Deretan berbagai macam gedung pencakar langit yang menjulang tinggi sudah menjadi pemandangan yang biasa di kota metropolitan ini. Hotel tersebut berfungsi sebagai sarana akomodasi pengunjung yang datang ke Jakarta untuk mengurusi urusan pekerjaan maupun untuk sekadar berwisata sebagai tempat menginap atau tempat tinggal sementara yang representatif.

\section{Tujuan Penulisan}

Menaikan aspek dibidang wisata di perkotaan tepatnya di kota Jakarta dan sekitarnya. Dengan naiknya bidang pariwisata dapat memberikan dampak positif ke berbagai bidang seperti ekonomi, social, budaya. 


\section{METODE}

Metode yang digunakan merupakan metode kualitatif dari Architectural Tourism by Jan Specht dan kuantitatif dari http://jakarta-tourism.go.id http://data.jakarta.go.id/dataset/datajumlah-wisatawan-pengunjung-museum. Metode yang digunakan dengan mengumpulkan informasi dari berbagai sumber seperti buku "Architectural Tourism by Jan Specht" dan berbagai ebook dan materi dari internet. Studi lapangan digunakan untuk mencari sebuah tapak untuk perancangan ini dibangun dan mencari informasi lebih lanjut dengan fakta sekitar yang ada. Ruang lingkup berdasarkan :

- Perancangan proyek wisata hiburan / pertunjukan di Jakarta.

- Wisata hiburan / pertunjukan apa yang dapat dikemabangkan di kota Jakarta.

\section{KAJIAN TEORI}

Metode Jan Specht menggambarkan dengan adanya wisata suatu daerah dapat "menaikan" sebuah daerah kurang mampu menjadi sebuah daerah yang berkecukupan dan terkenal.Galeri adalah ruangan atau gedung tempat memamerkan benda atau karya seni dan sebagainya (KBBI, 2018: https://kbbi.web.id/galeri). Wisata hiburan adalah segala sesuatu baik yang berbentuk kata-kata, tempat, benda, perilaku yang dapat menjadi penghibur atau pelipur hati yang susah atau sedih. Pada umumnya hiburan dapat berupa musik, film, opera, drama, ataupun berupa permainan bahkan olahraga. Berwisata juga dapat dikatakan sebagai upaya hiburan dengan menjelajahi alam ataupun mempelajari budaya. Mengisi kegiatan di waktu senggang seperti membuat kerajinan, keterampilan, membaca juga dapat dikatagorikan sebagai hiburan.

\section{HASIL DAN PEMBAHASAN}

Penerapan bidang yang ditetapkan dalam bidang ini adalah dengan memberikan kegiatan baru dalam sebuah pengalaman wisata di industri wisata di dalam sebuah perkotaan.

\section{Konsep dan Tema}

Konsep dan tema bangunan ini adalah sebuah galeri kesenian patung dan lukisan di mana pengunjung dapat berinteraksi dengan seni patung dan lukis itu sendiri sehingga pengunjung yang datang dapat merasakan pengalaman baru yang belum pernah merekarasakan.

Dengan tema kontemporer sehingga galeri tidak terkesan bosan dan kaku. Tetapi tetap mempertahankan bangunan iklim tropis sehingga utilitas air hujan tertutama tidak mengganggu galeri kesenian. Salah satu contoh tetap menggunakan atap portal sehingga air hujan turun dengan mudah, tetapi ditutup dinding tegak lurus sehingga tidak berkesan kuno.

\section{Hasil Rancangan}

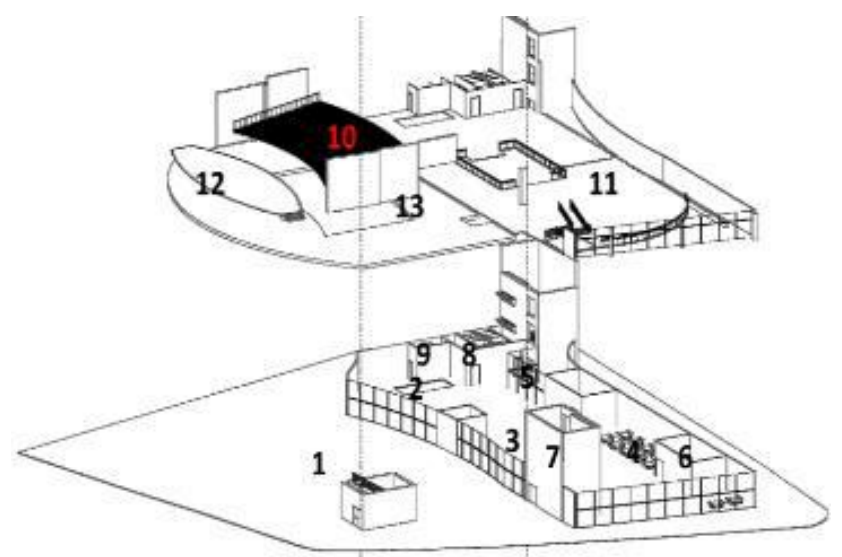

Gambar 1. Area lokakarya 
Denah di atas menunjukan area lokakarya. Dilengkapi taman dan kolam untuk view dan ketenangan pengunjung. Di atas lokakarya terdapat aduditorium dengan kegunaan akustik sehingga dapat memberikan pertunjukan maksimal.

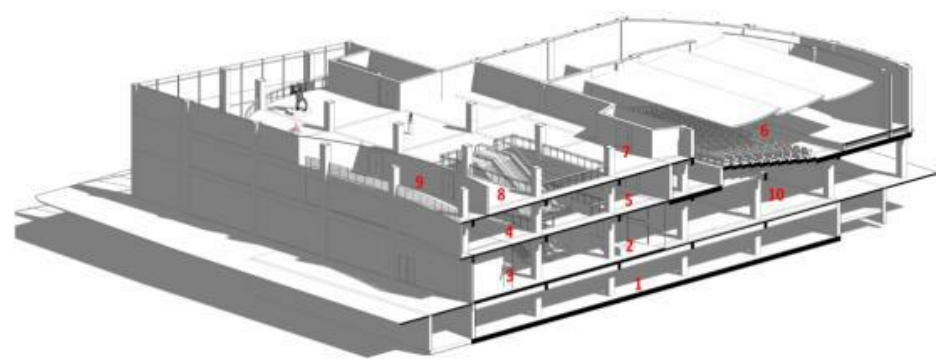

Gambar 2. Potongan perspektif

Lantai bawah digunakan untuk kegiatan komersil seperti restoran dan caffee yang diberi view ke lokakarya sehingga menambah kenyamanan restoran dan caffee tersebut.

Dibagian atas restoran terletak sebuah galeri kesenian yang berisi sebuah patung dan lukisan dengan dimensi kecil, sedang, dan besar dengan sebuah alur memutar sebuah galeri kesenian.

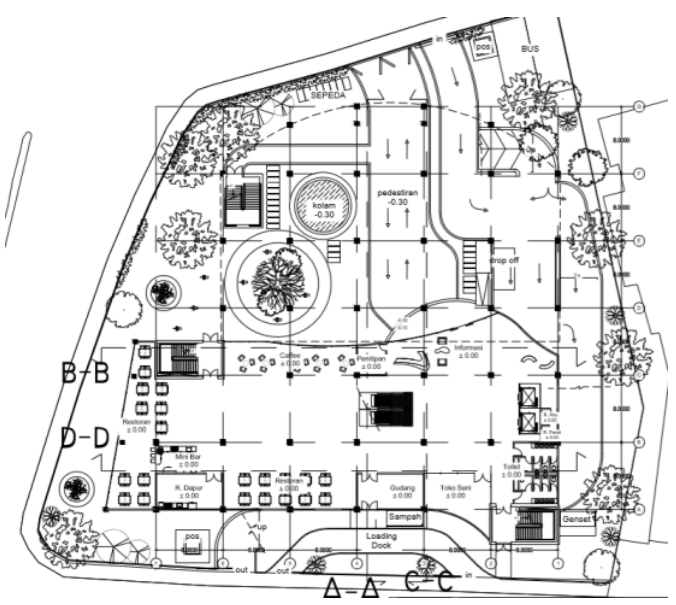

Gambar 3. Denah lantai satu

Berbagai fasilitas pendukung pastinya dilengkapi dengan parkir bus loading dan perputaran dalam tapak sehingga dapat memudahkan pengunjung memutar di tapak. Serta pedestrian yang tidak bertabrakan dengan jalur kendaraan.

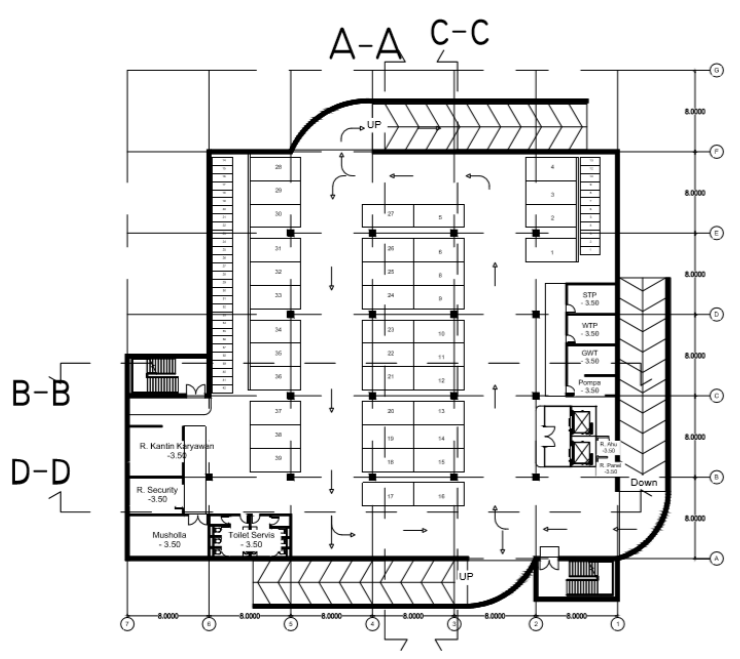

Gambar 4. Denah basement 
Kapasitas parkir mobil adalah 39 mobil dengan 42 motor dalam 1 lantai besment.

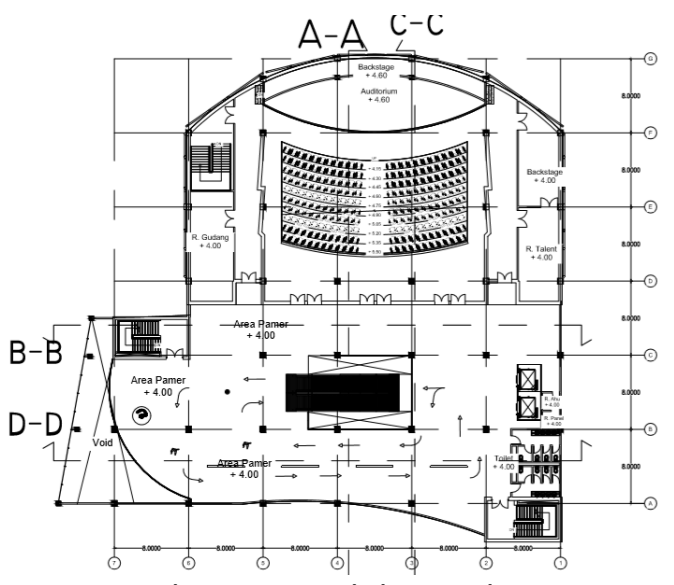

Gambar 5. Denah lantai dua

Dengan transportasi vertikal yaitu dua eskalator naik dan turun dan dua lift pengunjung sehingga kebutuhan transportasi ini dapat terpenuhi dengan baik untuk sirkulasi orang yang berada dalam galeri kesenian ini. Tidak hanya itu bagian auditorium juga dilengkapi dengan 3 pintu dengan 2 daun pintu sehingga arus sirkulasi yang terjadi tidak padat dan macet. Ruang penunjang pada auditorium ini seperti gudang peralatan pentas, ruang talent atau artis dan backstage juga tersedia.

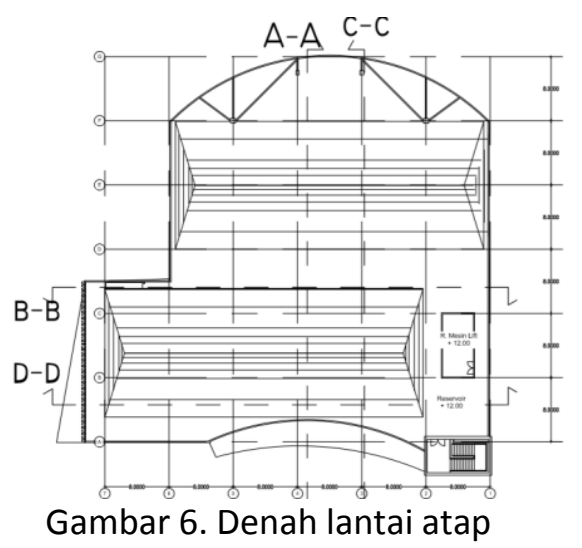

Atap bangunan menggunakan sebuah atap portal dengan zink aluminium sehingga kemiringan bisa mencapai $7^{\circ}$.

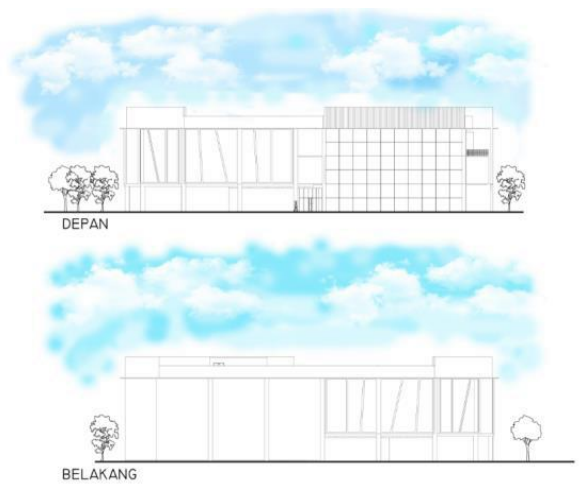

Gambar 7. Tampak depan dan belakang

Dengan penutup dinding tegak lulus maka bangunan tidak terlihat kuno dengan design atap miring layaknya rumah. 


\section{KESIMPULAN DAN SARAN}

Galeri kesenian memang bangunan yang terbilangrumit karena tidak adanya unsur pasti dalam sebuah galeri, belum lagi dengan berbagai alur bangunan yang berbeda-beda sehingga banyak arsitek membangun sebuah galeri dengan kreatfitas mereka dengan tampa batas. Namun hal itu sebenarnya bisa dibatasi dengan tetap berpegang teguh pada tema dan konsep yang ada. Serta fungsi galeri kesenian yang memberikan kesan hiburan dan pertunjukan baru yang memberikan pengalaman baru juga pada pengunjung galeri kesenian dalam tema Architourism of The Metropolis.

\section{REFERENSI}

Hermawan, H. (2017). Pengembangan Destinasi Wisata pada Tingkat Tapak Lahan dengan Pendekatan Analisis SWOT.

White, E. T. (1985). Analisis Tapak. Bandung: Intermatra.

Wijaya, Y. M. (1995). Kamus Besar Bahasa Indonesia. Jakarta: Erlangga.

Grafik pariwisata Jakarta, Agustus

https://marisapurnama1blog.wordpress.com/2016/02/18/perkembangan-industripariwisata-di-jakarta/

Presentase pengunjung pariwisata negara dan mancanegara, Agustus 2018 http://jakartatourism.go.id

Kompas.com, berita online, Agustus 2018 http:/kompas.com 